\title{
Technetium Tc-99m-NC100692
}

National Cancer Institute

\section{Source}

National Cancer Institute. Technetium Tc-99m-NC100692. NCI Thesaurus. Code C85458.

A synthetic Arg-Gly-Asp (RGD)-containing cyclic peptide radiolabeled with technetium Tc 99m with integrin-binding and radioisotopic activities. Upon administration, technectium Tc 99m-NC100692 binds to alpha5beta3 integrin and to a lesser extent alpha5beta5; subsequently, alpha5beta3-expressing tumor cells can be visualized using scintigraphy and the degree of tumor angiogenesis can be determined. Integ rins, membranespanning protein receptors, may be upregulated on proliferating endothelial cells; their overexpression has been associated with neovascularization, differentiation, proliferation of tumor cells and poor prognosis. 